\title{
Note on a Gallup-Purdue University Study and Related Articles: Useful Internships Improve University Graduates Chances of Full-Time Work
}

Romie Frederick Littrell, Auckland University of Technology, New Zealand

Several articles by Sean Seymour and Julie Ray summarize a Gallup-Purdue University (Gallup, Inc., 2014) study reported 20 November 2014, based upon the Gallup-Purdue Index, a jointresearch effort with Purdue University and Lumina Foundation, to study the relationship between the university experience and graduates'lives. The Gallup-Purdue Index is a comprehensive, nationally representative study of U.S. college graduates with Internet access, conducted February 4-March 7, 2014. According to a 2013 Census Bureau report, 90\% of university graduates in the U.S. have access to the Internet.

\section{Graduates' Odds of Being Employed Higher with Internships}

Authors Seymour and Ray (2014c) find that internships increase odds of full-time employment, and internships increase odds of engagement at work. Work and internship opportunities in university that allow students to apply what they learn improve the chances that graduates will find work after college. A Gallup-Purdue University study of college graduates finds $71 \%$ of the most recent graduates who strongly agreed that they had these types of jobs or internship opportunities as undergrads are working full time now for an employer, compared with $56 \%$ of those who strongly disagreed.

This relationship between applied internships and graduate employment should cause some currently enrolled college students to consider how they spend their time between now and graduation day. Seymour and Ray (2014b) report while the number of students taking advantage of internships has been rising across campuses, still relatively few of all university graduates report participating in these internship or job opportunities.

Table 1. Internships Increase Odds of Full-Time Employment for Graduates

\begin{tabular}{|l|c|c|}
\hline \multicolumn{3}{|c|}{ Percent employed full time for an employer } \\
\hline & Graduates 2010-2014 & Graduates prior to 2010 \\
\hline $\begin{array}{l}\text { Students selecting strongly agree } \\
\text { they took part in applied intern- } \\
\text { ships/jobs }\end{array}$ & $71 \%$ & $60 \%$ \\
\hline $\begin{array}{l}\text { Strongly disagree they took part in } \\
\text { applied internships/jobs }\end{array}$ & $56 \%$ & $52 \%$ \\
\hline
\end{tabular}

4 February - 7 March 2014 Gallup-Purdue Index, from: Seymour \& Ray (2014C)
The "employment benefit" for graduates who strongly agreed they had applied internships or jobs in college exists for all those who have earned their degrees in the past four years-regardless of gender, race, type of institution they graduated from, or whether they are the first in their families to attend university. Ray and Kafka (2014a) report from the Gallup-Purdue Index that what students do while in university, influenced by the opportunities their institutions afford them, can be more important than a number of other popularly proposed influential factors, including the type of school they attend.

\section{Graduates' Odds of Being Engaged at Work Higher with Internships}

Recent graduates who strongly agree they had an internship or job where they could apply what they were learning in college are not only more likely to have full-time employment, they are also more likely to be satisfactorily engaged at work. Fifty-six percent of employed recent graduates who took part in applied internships are engaged at workmeaning they are involved in and enthusiastic about their workcompared with 33\% of those who did not. This higher likelihood of engagement is good for these graduates, because engaged employees feel emotionally connected to the mission and purpose of their work, but it is also good for their employers. Engaged workers are the lifeblood of their organizations. Previous Gallup workplace engagement studies (e.g., Harter, Schmidt, Agrawal \& Plowman, 2014) show that business units scoring in the top half of their organization in employee engagement have nearly twice the odds of success, compared with those in the bottom half. 


\section{Survey Methods}

Results for this Gallup-Purdue Index study are based on Web interviews conducted February 4-March 7, 2014, with a random sample of 29,560 respondents with a bachelor's degree or higher, aged 18 and older, with Internet access, living in all 50 U.S. states and the District of Columbia.

\section{References}

Gallup, Inc. 2014. Great jobs, great lives: The 2014 Gallup-Purdue index inaugural national report. http://products.gallup.com/168857/ gallup-purdue-index-inaugural-national-report.aspx, accessed 21 November 2014.

Harter, J.K., Schmidt, F.L., Agrawal, S. \& Plowman, S.K. 2014. Global analytics: Gallup Q12 ${ }^{\circledR}$ Meta-Analysis: The relationship between engagement at work and organizational outcomes. Washington, DC: Gallup, Inc.

Ray, J., \& Kafka, S. 2014a. Life in college matters for life after college. Gallup Latest News, Economy: http://www.gallup.com/ poll/168848/life-college-matters-life-college.aspx, accessed 21 November 2014.

Seymour, S., \& Ray, J. 2014b. Recent grads more likely to have had useful internships. Gallup Latest News, Education: http://www.gallup. com/poll/179201/recent-grads-likely-useful-internships.aspx, accessed 14 November 2014.

Seymour, S., \& Ray, J. 2014c. Useful internships improve grads' chances of full-time work. Gallup Latest News, Education: http://www. gallup.com/poll/179516/useful-internships-improve-gradschances-full-time-work.aspx, accessed 20 November 2014.

Romie Littrell (Romie.Littrell@aut.ac.nz) is the Editor of AlB Insights, and associate professor of international business in the AUT Business School, Auckland University of Technology, New Zealand. His major research area is preferred leader behaviour across cultures. He facilitates two ongoing research consortia, the Centre for Cross Cultural Comparisons, see http://crossculturalcentre.homestead.com and the Leadership in Russia research group. For further information, see http://leadershipinrussia.homestead.com 